\title{
Aktualizacja Pisma Świętego według dokumentu Papieskiej Komisji Biblijnej „Interpretacja Biblii w Kościele” jako nowy sposób odniesienia słowa Bożego do życia
}

Celem niniejszego artykułu jest przedstawienie aktualizacji Pisma Świętego, o której mówi dokument Papieskiej Komisji Biblijnej Interpretacja Biblii w Kościele z 1993 roku ${ }^{1}$, jako nowego i wciąż nie dość zgłębionego sposobu odniesienia przesłania Biblii do życia współczesnych wierzących.

Kiedy zaglądamy do 4 tomów Bibliografi polskiej biblistyki opracowanej przez Piotra Ostańskiego, okazuje się, że od 1993 roku, czyli od ukazania się dokumentu, do 2009 roku pod hasłem „aktualizacja” znajdujemy jedynie trzy publikacje, z czego tylko dwa artykuły: Aktualizacja według Dokumentu Papieskiej Komisji Biblijnej „Interpretacja Biblii w Kościele”

${ }^{1} \mathrm{~W}$ artykule opieramy się na tłumaczeniu: Papieska Komisja Biblijna, Interpretacja Biblii w Kościele, tłum. R. Rubinkiewicz, [w:] Interpretacja Biblii w Kościele. Dokument Papieskiej Komisji Biblijnej z komentarzem biblistów polskich, red. R. Rubinkiewicz, Warszawa 1999, s. 24-102.

${ }^{2}$ R. Pindel, Aktualizacja wedtug Dokumentu Papieskiej Komisji Biblijnej „Interpretacja Biblii w Kościele”, [w:] Z badań nad Biblią, red. T. Jelonek, t. 5, Kraków 2002, s. 9-26. 
Romana Pindla oraz L'attualizzazione del messaggio biblico ${ }^{3}$ Jacka Uliasza dotyczą bezpośrednio aktualizacji omawianej przez Papieską Komisję Biblijną. Jest więc rzeczą konieczną podjąć temat aktualizacji, aby przynajmniej w małym stopniu zapełnić tę lukę.

\section{Aktualizacja według dokumentu Interpretacja Biblii w Kościele}

W ciągu dwóch tysięcy lat chrześcijaństwa wypracowano różne sposoby odnoszenia orędzia Pisma Świętego do życia wspólnoty wierzących. Niektóre z nich nie przetrwały próby czasu, inne natomiast, takie jak interpretacja alegoryczna, lectio divina, podejście fundamentalistyczne, akomodacja czy otwieranie Biblii „na chybił trafił”, wykorzystywane są po dzień dzisiejszy. Te wszystkie sposoby tworzą bogate tło, z którego wyłania się aktualizacja w takiej postaci, jaką prezentuje Papieska Komisja Biblijna. Taka aktualizacja jest czymś nowym, przede wszystkim ze względu na swe założenia metodologiczne i usystematyzowanie. Można powiedzieć, że wciąż jest czymś nowym, bo choć od ukazania się dokumentu minęły już ponad dwie dekady, to temat aktualizacji nie został wystarczająco zgłębiony.

Dokument Interpretacja Biblii w Kościele był pierwszym kościelnym dokumentem dotyczącym Biblii, który używał terminu „aktualizacja” w sensie dostosowania znaczenia Pisma Świętego do mentalności dzisiejszych ludzi ${ }^{4}$. Wcześniej termin ten stosowano w sakramentologii ${ }^{5}$. Nie oznacza to jednak, że pojęcie aktualizacji jest nowością w naukach biblijnych, funkcjonuje ono w biblistyce od wielu lat.

${ }^{3}$ J. Uliasz, Lattualizzazione del messaggio biblico, „Studia Sandomierskie. Filozofia Teologia - Historia” 14 (2007) z. 2-4, s. 321-347.

${ }^{4}$ Por. P. S. Williamson, Catholic principles for interpreting Scripture, „Catholic Biblical Quarterly” 65 (2003) nr 3, s. 346.

${ }^{5}$ Por. M. Girard, Dokument Papieskiej Komisji Biblijnej „Interpretacja Biblii w Kościele” - bilans i perspektywy, „Verbum Vitae” 2003 nr 4, s. 282. 
Słowo „aktualizacja” jest tłumaczeniem francuskiego terminu actualiser użytego w oryginalnej francuskiej wersji dokumentu, który oznacza „uczynić obecnym do dzisiaj”.

\subsection{Miejsce aktualizacji}

Aby właściwie zrozumieć tekst dotyczący aktualizacji, należy zaznaczyć kontekst wypowiedzi na jej temat, czyli cały dokument Interpretacja Biblii $w$ Kościele, który stanowi kontekst bliższy ${ }^{7}$.

Tekst dotyczący aktualizacji autorzy umieścili w czwartej części dokumentu, która nosi tytuł Interpretacja Biblii w życiu Kościoła. Rozdział ten porusza trzy zagadnienia, każde omówione w odrębnym podrozdziale. Pierwsze zagadnienie to właśnie aktualizacja, drugie - inkulturacja, natomiast trzeci podrozdział zatytułowany Korzystanie $z$ Biblii podzielony jest na cztery podpunkty: W liturgii, Lectio divina, W postudze duszpasterskiej oraz $W$ ekumenizmie. Fakt, iż aktualizacja omówiona jest jako pierwsza, oznacza, że stanowi podstawę do rozważań podjętych w dalszej części dokumentu. Problem aktualizacji jest fundamentalny, ponieważ bez niego nie da się poprawnie przeprowadzić inkulturacji. Najpierw należy dostosować przesłanie tekstów biblijnych do czasów, w których żyje człowiek, a następnie można dostosować to przesłanie do obecnego rozwoju kultury w różnych miejscach świata. Podobnie dzieje się w przypadku zagadnień poruszanych w rozdziale Korzystanie $z$ Biblii, ponieważ wymienione w nim sposoby również dokonują się w konkretnym czasie i miejscu.

We wstępie do czwartej części dokumentu zamieszczono uwagi, które bezpośrednio łączą ją z poprzednią, dotyczącą specyficznego wymiaru katolickiej interpretacji Pisma Świętego. U źródła tych uwag możemy odnaleźć reakcję na niewłaściwe stosowanie metody historyczno-krytycznej

${ }^{6}$ Por. P. S. Williamson, Actualization: a new emphasis in catholic Scripture study, „America” 1995 nr 172, s. 17.

${ }^{7}$ Bardzo ważny jest również kontekst dalszy, który tworzy nauczanie Kościoła w XX wieku, a w szczególności Konstytucja dogmatyczna o Objawieniu Bożym Soboru Watykańskiego II. Zagadnienie to omawia Roman Pindel w artykule Aktualizacja..., dz. cyt. 
oraz ograniczanie się tylko do naukowej analizy tekstów. Dlatego na samym początku autorzy stwierdzają: „Egzegeci, których szczególnym zadaniem jest interpretacja Biblii, nie mają jednak monopolu na nią"8. Dzieje się tak, ponieważ Pismo Święte posiada wymiary przekraczające kompetencje naukowej interpretacji. Następnie Komisja stwierdza, że Kościół nie traktuje Biblii jedynie jako starożytnego zbioru historycznych pism, lecz jako słowo Boże. Autorzy zaznaczają także, że adresatem słowa Bożego jest zarówno wspólnota Kościoła, jak również cały współczesny świat. Na końcu wstępu komisja wymienia konkretne działania będące owocem tego szczególnego traktowania Biblii przez Kościół: aktualizacja, inkulturacja, liturgia, lectio divina, duszpasterstwo oraz ekumenizm. Praktyki te wyrażają wiarę Kościoła w żywe słowo Boże?

We wstępie do punktu dotyczącego aktualizacji autorzy dokumentu sygnalizują, że z kwestią aktualizacji łączą się zagadnienia poruszane zwłaszcza w dwóch punktach trzeciej części dokumentu, a mianowicie z interpretacją Pisma Świętego w tradycji biblijnej oraz w Tradycji Kościoła. Zarówno praktyka autorów natchnionych, którzy odczytywali starsze teksty biblijne w kontekście nowej rzeczywistości, jak i interpretacja aktualizująca w Tradycji Kościoła stanowią pierwowzór współczesnej aktualizacji ${ }^{10}$.

\subsection{Zasady aktualizacji}

Autorzy dokumentu ustalili pięć zasad, które mają fundamentalne znaczenie dla aktualizacji. Pierwsza zasada mówi o możliwości aktualizacji. Otóż, aktualizacja jest możliwa, ponieważ teksty biblijne posiadają pełnię sensu, która „nadaje im wartość dla wszystkich epok i wszystkich kultur”11. Dla poparcia ponadczasowej aktualności tekstów biblijnych autorzy dokumentu odwołują się do trzech fragmentów Pisma Świętego: Iz 40, 8; 66, 18-21; Mt 28, 19-20. Te biblijne cytaty mówią o trwałości i uniwersalności

\footnotetext{
${ }^{8}$ Papieska Komisja Biblijna, Interpretacja..., dz. cyt., s. 87.

${ }^{9}$ Por. R. Pindel, Aktualizacja..., dz. cyt., s. 10

${ }^{10}$ Por. tamże, s. $10-11$.

${ }^{11}$ Papieska Komisja Biblijna, Interpretacja..., dz. cyt., s. 87.
} 
Bożego dzieła, nie tłumaczą, jednak owej pełni sensu tekstu biblijnego ${ }^{12}$. We francuskim oryginale dokumentu autorzy użyli wyrażenia plénitude de sens du texte biblique. Na znaczenie tych słów może nas naprowadzić angielskie tłumaczenie, którego dokonał Fitzmyer. Używa on zwrotu richness of meaning. W języku polskim podobne tłumaczenie odnajdujemy w przekładzie Kazimierza Romaniuka - „bogactwo znaczeniowe”

Wyrażenie richness of meaning możemy odnaleźć u Ricoeura. Używa go, omawiając symboliczny charakter języka biblijnego, który będąc niewyczerpanym, ukierunkowuje na transcendentną rzeczywistość oraz rozbudza nasze pragnienia ${ }^{14}$. Dokument już wcześniej, w rozdziale Znaczenie Pisma natchnionego mówi na ten temat: „Tok współczesnej hermeneutyki podkreślił różnice statusu ludzkiego słowa, kiedy zostaje ono sformułowane na piśmie. Tekst pisany ma tę właściwość, że można go umieścić w nowych okolicznościach, które naświetlają go na różne sposoby, dorzucając do jego znaczenia nowe możliwości. Ta właściwość tekstu pisanego jest szczególnie widoczna w przypadku tekstów biblijnych uznanych za Słowo Boże. W rzeczy samej przekonanie, że niezmiennie niosą one światło i życie dla przyszłych pokoleń, doprowadziło społeczność wierzącą do zachowania ich. Sens wyrazowy jest od początku otwarty na dalszy rozwój, który powstaje dzięki «relekturze» w nowym kontekście”15.

Każdy literacki tekst, a w szczególności Biblia, posiada znaczenie, które wychodzi poza siebie. Zarówno w przeszłości, jak i teraz ludzie, czytając Biblię, zadają sobie pytania charakterystyczne dla swoich czasów, a Pismo Święte rzuca światło na współczesne im problemy ${ }^{16}$. Tak więc

${ }^{12}$ Por. R. E. Murphy, Reflections on „actualization” of the Bible, „Biblical Theology Bulletin” 26 (1996) nr 2, s. 79.

${ }^{13}$ Papieska Komisja Biblijna, Interpretacja Pisma Świętego w Kościele. Przemówienie Ojcaświętego Jana Pawła II oraz Dokument Papieskiej Komisji Biblijnej, tłum. K. Romaniuk, Poznań 1994, s. 98.

${ }^{14}$ P. Ricoeur omawia ten temat m.in. w Interpretation Theory: Discourse and the Surplus of Meaning, Fort Worth 1976.

${ }^{15}$ Papieska Komisja Biblijna, Interpretacja..., dz. cyt., s. 63.

${ }^{16}$ Por. P. S. Williamson, Catholic principles for interpreting Scripture: a study of the Pontifical Biblical Commission's "The interpretation of the Bible in the Church", Roma 
w każdym czasie realna jest aktualizacja odciskająca piętno na życiu czytelników Pisma Świętego, którego teksty odnoszą się do innych czasów ${ }^{17}$.

Druga zasada dotyczy konieczności aktualizacji. Aktualizacja Pisma Świętego jest konieczna, ponieważ słowo Boże, które znajdujemy w Biblii, stoi w określonej odległości od nas pod względem języka, kultury, kontekstu. Historyczne uwarunkowania Pisma Świętego nie posiadają absolutnej wartości ${ }^{18}$, dlatego też jego przesłanie, jak czytamy w dokumencie, musi być wydobyte $\mathrm{z}$ historycznych uwarunkowań przeszłości i zastosowane do współczesnych realiów, jak również wyrażone językiem ludzi współczesnych $^{19}$. Ażeby tego dokonać, należy podjąć wysiłek hermeneutyczny, którego celem jest dotarcie do istoty orędzia biblijnego. Należy więc uwzględnić zasady naukowe i teologiczne interpretacji Pisma Świętego ${ }^{20}$.

Trzecia zasada dotyczy relacji pomiędzy Starym i Nowym Testamentem, którą koniecznie należy uwzględnić, aby dokonać poprawnej aktualizacji $^{21}$. Relację tę autorzy dokumentu nazywają „dynamiczną jednością”, która objawia się w tym, że Nowy Testament jest zarówno „wypełnieniem”, jak i „przewyższeniem” Starego Testamentu.

Przedostatnia, czwarta zasada dotyczy eklezjalnego i wspólnotowego charakteru aktualizacji ${ }^{22}$. W dokumencie czytamy: „Aktualizacja dokonuje się dzięki dynamizmowi żywej tradycji wspólnoty wiary. Ta zaś sytuuje się wyraźnie w przedłużeniu wspólnot, w których Pismo Święte się narodziło, zostało przechowane i przekazane"23. O ile poprzednia zasada skupiała się na relacjach wewnątrzbiblijnych, ta dotyka zagadnienia relacji pomiędzy Pismem Świętym a Tradycją. Pismo Święte powstało w obrębie Tradycji,

2001, s. 292.

${ }^{17}$ Por. R. Pindel, Aktualizacja..., dz. cyt., s. 14.

${ }^{18}$ Komisja stwierdza to omawiając zagadnienie relacji pomiędzy egzegezą a teologią dogmatyczną - por. Papieska Komisja Biblijna, Interpretacja..., dz. cyt., s. 84.

${ }^{19}$ Por. Papieska Komisja Biblijna, Interpretacja..., dz. cyt., s. 87-88.

${ }^{20}$ Por. R. Pindel, Aktualizacja..., dz. cyt., s. 15.

${ }^{21}$ Tę relację dokument omawia w części trzeciej dokumentu zatytułowanej Charakterystyczny wymiar interpretacji katolickiej w rozdziale Interpretacja $w$ Tradycji biblijnej.

${ }^{22}$ Por. R. Pindel, Aktualizacja..., dz. cyt., s. 16.

${ }^{23}$ Papieska Komisja Biblijna, Interpretacja..., dz. cyt., 88. 
w ramach której następnie pogłębiano jego rozumienie i wcielano w życie jego orędzie. Dokonując więc aktualizacji, nie możemy ograniczać się jedynie do Pisma Świętego, ale musimy brać pod uwagę Tradycję, dzięki której aktualizacja się dokonuje. Tutaj dochodzimy do aspektu eklezjalnego aktualizacji, ponieważ zgodnie z nauką Soboru Watykańskiego II Pismo Święte i Tradycja „stanowią powierzony Kościołowi jeden święty depozyt Słowa Bożego" ${ }^{24}$. Biblia jest pismem Kościoła, dlatego nie można jej od niego oddzielić. Żywa Tradycja posiada podwójną rolę: negatywną, gdy chroni przed niewłaściwą interpretacją, oraz pozytywną, która objawia się w przekazie pierwotnego dynamizmu.

Ostatnia, piąta zasada mówi na temat właściwego podejścia do aktualizacji i jest konsekwencją poprzedniej zasady. Autorzy dokumentu stwierdzają, że aktualizacja nie może być równoznaczna $\mathrm{z}$ manipulacją tekstem, kiedy to zamiast słuchać tego, co tekst chce nam przekazać, przenosimy własne poglądy na tekst. Poprawną aktualizację powinno cechować „szczere szukanie światła”"25, którym teksty biblijne rozświetlają współczesność. Jest tak dlatego, ponieważ Biblia to autorytatywny przewodnik dla Kościoła. Na samym końcu komisja przypomina o właściwym stosunku magisterium Kościoła do Pisma Świętego. Przytacza tekst konstytucji soborowej Dei Verbum: „Magisterium Kościoła nie jest ponad Słowem Bożym, ale mu służy, ucząc tylko tego, co zostało mu przekazane. Z Bożego mandatu, z pomocą Ducha Świętego słucha go z miłością, święcie strzeże i wiernie wyjaśnia" ${ }^{26}$.

\subsection{Metody aktualizacji}

Po omówieniu założeń, na których powinna opierać się każda prawidłowa aktualizacja, autorzy dokumentu wskazują drogi, jakimi należy aktualizować przesłanie tekstów biblijnych. Czynią to w drugim podrozdziale zatytułowanym Metody.

${ }^{24}$ Sobór Watykański II, Konstytucja dogmatyczna o Objawieniu Bożym „Dei Verbum”, Wrocław 2003, nr 10.

${ }^{25}$ Papieska Komisja Biblijna, Interpretacja..., dz. cyt., 88.

${ }^{26}$ Sobór Watykański II, Konstytucja dogmatyczna..., dz. cyt., 10. 
Na wstępie należy zaznaczyć pewien problem dotyczący tego podrozdziału - chodzi mianowicie o jego podział. Otóż nie ma zgodności wśród interpretatorów dokumentu co do struktury tego podrozdziału. Fitzmyer, komentując dokument, pisze, że w podrozdziale poświęconym metodom komisja wyróżnia cztery sposoby, za pomocą których można aktualizować Biblię. Są to żydowskie techniki egzegetyczne, typologia i alegoria stosowana niegdyś przez ojców Kościoła, interpretacja Pisma za pomocą Pisma oraz hermeneutyka filozoficzna ${ }^{27}$. Takiemu podziałowi sprzeciwia się Williamson, który stwierdza, że nie jest możliwe, aby Komisja chciała zaprezentować rabiniczne i patrystyczne metody jako obowiązujące dzi$s^{2}{ }^{28}$. Autor ten wyróżnia w tekście trzy części. Pierwsza ilustruje wielość możliwych metod poprzez odwołanie się do przykładów interpretacji żydowskiej i patrystycznej. Druga zawiera wskazówki dotyczące aktualizacji ze szczególnym uwzględnieniem współczesnych sposobów myślenia oraz metod. Trzecia część jest analizą wyprowadzonych z hermeneutyki filozoficznej wymogów, które musi spełniać aktualizacja ${ }^{29}$.

Najlepiej jednak strukturę tego podrozdziału uchwycili m.in. Pindel i Murphy. Również wyróżniają trzy części, jednak nadają im inny charakter. Pierwsza część mówi o metodach wykorzystywanych w przeszłości,

${ }^{27}$ Por. J. A. Fitzmyer, The Biblical Commission's document „The interpretation of the Bible in the Church", Roma 1995, s. 173.

${ }^{28}$ Por. P. S. Williamson, Catholic principles for interpreting Scripture..., dz. cyt., s. 297. W swym komentarzu do dokumentu Fitzmyer pisze, jakby uprzedzając taki zarzut, że komisja, zalecając jako sposób aktualizacji typologię i alegorię, nie neguje tego, co wcześniej powiedziano o niemożliwości stosowania takiej interpretacji dzisiaj, gdyż interpretacja alegoryczna może być przyczyną dezorientacji współczesnych ludzi. Według niego, aby rozwiązać ten problem, należy wziąć po uwagę słowa Piusa XII z encykliki Divino afflante Spiritu dotyczące zagrożenia, jakie niesie sens figuratywny. Jednak te słowa nie zmieniają faktu, że podział zastosowany przez Fitzmyera jest niewłaściwy m.in. dlatego, że nie bierze pod uwagę kryterium czasowości.

${ }^{29}$ P. S. Williamson, Catholic principles for interpreting Scripture..., dz. cyt., s. 297. Podobny podział do przedstawionego przez Williamsona można znaleźć w: M. Laconi, Nella vita della Chiesa, [w:] Pontificia Commissione Biblica, L'interpretazione della Bibbia nella Chiesa. Commento, a cura di G. Ghiberti, F. Mosetto, Torino 1998, s. 365-366. 
druga zawiera wskazania dotyczące aktualizacji przeprowadzanej w dzisiejszych czasach, natomiast w trzeciej części zostają wymienione etapy, które należy koniecznie uwzględnić, przeprowadzając aktualizację ${ }^{30}$. My przyjmujemy ten podział.

Pierwsza część tego podrozdziału dotyczy więc metod aktualizacji, jakie wykorzystywano w przeszłości. Celem tej części jest wskazanie na bogate spektrum sposobów aktualizacji, a także podanie właściwych przykładów aktualizacji, jakiej dokonywano w środowisku judaizmu oraz ojców Kościoła ${ }^{31}$.

Na początku omówienia drugiej części podrozdziału warto zaznaczyć, że mimo iż podrozdział ten nosi tytuł Metody, komisja nie wskazuje konkretnych metod, jakie dzisiaj powinny być stosowane, lecz podaje pewne wskazania oraz cechy, które należy uwzględnić, aktualizując Pismo Święte. Część ta zaczyna się od zdania: „W naszej epoce aktualizacja musi brać pod uwagę ewolucję mentalności i postęp metod interpretacji”" ${ }^{32}$. Roman Pindel wyróżnia dwa wymiary tego wskazania. Pierwszy wymiar nazywa antropologiczno-kulturowym ${ }^{33}$. Osoba dokonująca aktualizacji, aby jej praca była poprawna i owocna, musi wziąć pod uwagę, w jakiej rzeczywistości żyje współczesny człowiek. Chodzi tu o jego język, sposób myślenia, życiowe doświadczenia, kulturę, założenia filozoficzne, stan wie$\mathrm{dzy}^{34}$. Nie można przecież, aktualizując Pismo Święte dla współczesnego człowieka, posługiwać się kategoriami czy problematyką z przeszłości, które w żaden sposób do czytelnika nie przemawiają. Taka aktualizacja byłaby zaprzeczeniem samej siebie. Drugi wymiar pierwszego wskazania Pindel nazywa metodologicznym ${ }^{35}$. Podkreśla on, że osoba dokonująca

${ }^{30}$ Por. R. Pindel, Aktualizacja..., dz. cyt., s. 17 oraz R. E. Murphy, Reflections on „actualization" of the Bible..., dz. cyt., s. 80-81.

${ }^{31}$ Por. R. Pindel, Aktualizacja..., dz. cyt., s. 17.

${ }^{32}$ Papieska Komisja Biblijna, Interpretacja..., dz. cyt., s. 89.

${ }^{33}$ Por. R. Pindel, Aktualizacja..., dz. cyt., s. 18.

${ }^{34}$ Por. S. Haręzga, Droga Słowa Bożego od zrozumienia do inkulturacji, [w:] Interpretacja Biblii w Kościele. Dokument Papieskiej Komisji Biblijnej z komentarzem biblistów polskich, przekł. i red. R. Rubinkiewicz, Warszawa 1999, s. 209.

${ }^{35}$ Por. R. Pindel, Aktualizacja..., dz. cyt., s. 18. 
aktualizacji musi uwzględniać postęp $\mathrm{w}$ dziedzinie metod interpretacji Pisma Świętego i szukać takiej metody, która najlepiej odpowiada wymogom aktualizacji. Nie można kurczowo trzymać się jednej metody, lecz należy mieć umysł nieustannie otwarty na nowe sposoby interpretacji.

Wskazanie drugie dotyczy podstawowej kwestii, bez której nie przeprowadzi się aktualizacji, chodzi mianowicie o „poprawną egzegezę"36 tekstu. Poprzez poprawną egzegezę autorzy rozumieją tutaj takie działanie, które odkrywa dosłowny sens tekstu biblijnego. Innymi słowy, każda aktualizacji musi zaczynać się od ustalenia sensu dosłownego tekstu. Konieczne jest więc uwzględnienie krytyki biblijnej ${ }^{37}$.

W trzecim wskazaniu Komisja sugeruje metodę, która według niej najlepiej nadaje się dla aktualizacji. W tekście czytamy, że jest to metoda „najpewniejsza i najbardziej płodna" ${ }^{38}$. Jest nią interpretacja Pisma Świętego za pomocą Pisma Świętego ${ }^{39}$. W dokumencie czytamy, że metoda ta jest szczególnie owocna, gdy zajmujemy się tekstami Starego Testamentu, które zostają ponownie zastosowane w Starym lub Nowym Testamencie ${ }^{40}$.

Czwarte wskazanie brzmi następująco: „Aktualizacja Pisma Świętego w chrześcijańskiej egzystencji nie może być poprawna bez usytuowania jej wobec tajemnicy Chrystusa i Kościoła" ${ }^{31}$. Związek aktualizacji z tajemnicą Chrystusa oznacza, że w centrum interpretacji musi stać życie, nauka, śmierć i zmartwychwstanie Chrystusa. Wynika z tego, że nie można

${ }^{36}$ Papieska Komisja Biblijna, Interpretacja..., dz. cyt., s. 89.

${ }^{37}$ Komisja daje również wskazówkę dla tych, którzy nie posiadają naukowego przygotowania egzegetycznego. Zaleca się im korzystanie z komentarzy i innej literatury egzegetycznej.

${ }^{38}$ Papieska Komisja Biblijna, Interpretacja..., dz. cyt., s. 89.

${ }^{39}$ R. E. Murphy pisze, że to stanowisko jest zaskakujące, ponieważ przyjmuje zasadę Reformacji Scriptura sui interpres. Jednak zdziwienie amerykańskiego biblisty jest samo w sobie czymś dziwnym, gdyż autorzy dokumentu wyraźnie odnoszą się do sposobu interpretowania Pisma przez Pismo, jaki cechował egzegezę patrystyczną, a nie zasadę hermeneutyczną głoszoną przez Lutra.

${ }^{40}$ Autorzy podają przykład motywu manny z Wj 16, który poruszany jest w Mdr 16, 20-29 oraz w J 6.

${ }^{41}$ Papieska Komisja Biblijna, Interpretacja..., dz. cyt., s. 89. 
zatrzymywać się na sensie dosłownym, lecz należy, o ile jest to możliwe, poszukiwać sensu duchowego, który Komisja definiuje jako sens tekstu czytanego pod natchnieniem Ducha Świętego „w kontekście Tajemnicy Paschalnej Chrystusa i nowego życia, które z niego wynika" ${ }^{42}$. Mówiąc o konieczności uwzględnienia związku aktualizacji z tajemnicą Kościoła, autorzy pragnęli zaznaczyć, że aktualizacja musi uwzględniać kontekst eklezjalny, a co za tym idzie - Tradycję. Haręzga widzi w tym wskazaniu również wymiar pneumatologiczny. Aktualizacja oprócz tego, że jest pracą człowieka, jest również darem Ducha Świętego, który pozwala dostrzec tajemnicę Chrystusa i Kościoła. Owoce przeprowadzonej aktualizacji są warunkowane otwartością i wiernością Duchowi Świętemu ${ }^{43}$.

\subsection{Etapy aktualizacji}

W ostatniej części podpunktu dotyczącego metod aktualizacji, autorzy dokumentu podają trzy kroki, które należy spełnić, aby poprawnie przeprowadzić aktualizację. Owe kroki zostały sformułowane w oparciu o współczesne kierunki filozofii hermeneutycznej, które w dokumencie zostały omówione w części drugiej zatytułowanej Kwestie hermeneutyczne ${ }^{44}$.

Pierwszy etap aktualizacji został określony następująco: „słuchanie

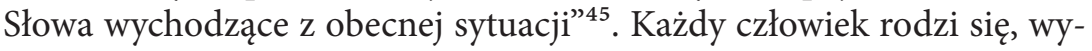
chowuje i żyje w konkretnej rzeczywistości, która ma wpływ na jego relacje do siebie samego oraz do małych i dużych wspólnot, takich jak rodzina, Kościół czy ludzkość, a także na jego relację do Boga. Na tę rzeczywistość składają się nie tylko takie czynniki jak język, kultura, rozwój cywilizacyjny, lecz również choćby najmniejsze wzloty i upadki, których doświadcza człowiek, smutek i szczęście, samotność lub bycie-z-kimś. Zanim więc przystąpimy do aktualizacji orędzia biblijnego,

42 Tamże, s. 64.

${ }^{43}$ Por. S. Haręzga, Droga Słowa Bożego..., dz. cyt., s. 209.

${ }^{44} \mathrm{~W}$ pierwszym rozdziale tej części zostali wspomniani tacy autorzy, jak F. Schleiermacher, W. Dilthey, M. Heidegger, R. Bultmann, H. G. Gadamer oraz P. Ricoeur. Poglądy trzech ostatnich filozofów zostały omówione szerzej w podrozdziale Współczesne perspektywy.

${ }^{45}$ Papieska Komisja Biblijna, Interpretacja..., dz. cyt., s. 89. 
należy poznać, w jakiej sytuacji, rzeczywistości żyje człowiek, któremu będziemy głosić Ewangelię. Konieczne jest więc na samym początku dokonanie wnikliwej analizy antropologicznej problemów współczesnego świata i człowieka. Również przedrozumienie osoby aktualizującej odgrywa tu ważną rolę. Kiedy poznamy owe problemy, przystępujemy do słuchania słowa Bożego ${ }^{46}$.

Tutaj dochodzimy do drugiego etapu aktualizacji. Kiedy już poznaliśmy kwestie antropologiczne i zaczęliśmy słuchać słowa Bożego, musimy skonfrontować rzeczywistość ze słowem. Komisja wyraża to następująco: „rozpoznanie aspektów obecnej sytuacji, które tekst biblijny naświetla lub kwestionuje" ${ }^{37}$. Dzięki tej konfrontacji określamy, do których wymiarów obecnej sytuacji Pismo Święte się ustosunkowuje. Aktualizacja wymaga więc umiejętnego rozpoznania tych aspektów. Następnie te wymiary są oceniane przez Pismo Święte.

Trzeci etap aktualizacji sformułowano następująco: „wydobycie z pełnego sensu tekstu biblijnego elementów zdolnych płodnie przekształcić obecną sytuację, zgodnie ze zbawczą wolą Boga w Chrystusie"48. Po skonfrontowaniu współczesnej sytuacji z orędziem Pisma Świętego, a co za tym idzie, po odkryciu, iż istnieją takie wymiary tej sytuacji, do których teksty biblijne się odnoszą, oraz po określeniu tych wymiarów, osoba przeprowadzająca aktualizację musi zagłębić się w tekst Pisma Świętego w poszukiwaniu elementów, które pomogą jej przemienić rzeczywistość. Autorzy stwierdzają, że ta przemiana musi być zgodna z wolą Boga, nie ma więc miejsca na manipulację.

Na samym końcu podrozdziału dotyczącego metod aktualizacji komisja wymienia kwestie, które warto szczególnie podjąć poprzez aktualizację. Są to np. wspólnotowy charakter Kościoła, urzędy, pomoc ubogim czy status społeczny kobiet. Ponadto podane zostają wartości, na

${ }^{46}$ Roman Pindel wskazuje na istotność posłużenia się przez autorów słowem „słuchać”. Twierdzi on, że autorzy wybrali ten termin, aby wskazać zarówno na słuchanie wspólnotowe, jak i indywidualne - por. R. Pindel, Aktualizacja..., dz. cyt., s. 21.

${ }^{47}$ Papieska Komisja Biblijna, Interpretacja..., dz. cyt., s. 89.

48 Tamże. 
które należy zwracać uwagę, takie jak prawa człowieka, ochrona życia, pokój oraz ekologia.

\subsection{Granice aktualizacji}

Ostatni podrozdział tej części dokumentu dotyczącej aktualizacji nosi tytuł Granice. Wymienione są w nim granice, których nie należy przekraczać, aktualizując Pismo Święte. Po pierwsze należy wystrzegać się selektywności przy dobieraniu tekstów. Chodzi tu przede wszystkim o postawę, która objawia się w wykorzystywaniu tekstów biblijnych do poparcia konkretnych poglądów, a nie wczytywanie się w to, co tekst chce mi przekazać. Dzieje się tak często w różnego typu sektach, autorzy wymieniają tutaj Świadków Jehowy.

Druga przestroga mówi, że aktualizacja nie może opierać się na założeniach sprzecznych z fundamentalną nauką Pisma Świętego. Autorzy wymieniają dwa kierunki filozoficzne, od których nie można rozpoczynać aktualizacji - są to racjonalizm i ateistyczny materializm.

W trzeciej uwadze autorzy dokumentu stwierdzają, że trzeba „odrzucić wszelką aktualizację ukierunkowaną na sprzeciw wobec sprawiedliwości i miłości ewangelicznej”9 ${ }^{3}$. Przykładem takiej niewłaściwej aktualizacji jest uzasadnianie tekstami Pisma Świętego rasizmu, antysemityzmu lub wyższości jednej płci nad drugą. Nie tylko nie można aktualizować tekstów Nowego Testamentu w taki sposób, który nakłaniałby do antysemityzmu, lecz również powinno się powtarzać, że „Żydzi są nadal kochani przez Boga" ${ }^{\text {"50 }}$.

Następnie zostaje wskazana droga, na której uniknie się powyższych dewiacji. Komisja po raz kolejny zaznacza, iż aktualizację należy rozpoczynać od „poprawnej interpretacji tekstu” ${ }^{11}$ Pisma Świętego, a następ-

${ }^{49}$ Por. tamże, dz. cyt., s. 90.
${ }^{50}$ Por. tamże, s. 90.
${ }^{51}$ Por. tamże, dz. cyt., s. 90. Z poprzednich wypowiedzi wynika, że poprzez poprawną interpretację autorzy rozumieją zarówno dotarcie do sensu dosłownego tekstu, jak i odkrycie jego sensu duchowego. 
nie przeprowadzać ją zgodnie z Magisterium Kościoła, biorąc pod uwagę żywą Tradycję Kościoła ${ }^{52}$.

Ostatni akapit podrozdziału o granicach aktualizacji i zarazem ostatni całego rozdziału poświęconego aktualizacji zawiera inspirację do praktykowania aktualizacji. Aktualizacja jest konieczna i pewne zagrożenia, które jej towarzyszą, nie powinny sprawić, że zostanie zaniechana.

\section{Definicja aktualizacji}

Po omówieniu wypowiedzi na temat aktualizacji zawartych w dokumencie Papieskiej Komisji Biblijnej postaramy się teraz usystematyzować wszystkie informacje w celu opracowania definicji aktualizacji, która wynika $z$ dokumentu.

Próbę zdefiniowania aktualizacji na podstawie dokumentu Interpretacja Biblii w Kościele podją Fitzmyer w artykule Concerning the Interpretation of the Bible in the Church. Określa on aktualizację jako jedynie „aspekt sensu dosłownego" Pisma Świętego i wyłącznie „budowanie na właściwie ustalonym sensie dosłownym"53. Autor, jak widzimy, mimo wypowiedzi Komisji na temat konieczności uwzględnienia tajemnicy Chrystusa i Kościoła, która jest wyraźnym wskazaniem, aby odkrywać sens duchowy tekstów biblijnych, a także uwzględniać Tradycję, zawęża aktualizację wyłącznie do procesu aplikacji sensu dosłownego ${ }^{54}$.

${ }^{52}$ Jest to kolejne odwołanie do zasad teologicznych interpretacji Pisma Świętego opracowanych w konstytucji dogmatycznej Dei Verbum Soboru Watykańskiego II - por. R. Pindel, Aktualizacja..., dz. cyt., s. 26.

${ }^{53}$ J. A. Fitzmyer, Concerning the Interpretation the Bible in the Church, [w:] The interpretation of Scripture. In defense of the historical-critical method, New York-Mahwah 2008, s. 84.

${ }^{54}$ Oczywiście istnieją teksty, których sens dosłowny jest jednocześnie sensem duchowym. Dzieje się tak w przypadku tekstów, które odnoszą się wprost do tajemnicy paschalnej. Jednak Fitzmyer nie rozpatruje takich przypadków, a jedynie stwierdza, że aktualizacja tylko rozciąga sens dosłowny, aby pokazać, że to, co było powiedziane, ma 
Aktualizację można zdefiniować jako możliwy i konieczny proces odniesienia przesłania Pisma Świętego do czasów współczesnych, który przedstawia zarówno sens dosłowny tekstu biblijnego, jak i jego chrystologiczny, kanoniczny i eklezjalny wymiar, bez manipulowania tekstem, lecz poszukujący światła, które Pismo Święte rzuca na czasy współczesne, po to, aby odmienić nasze życie zgodnie w wolą Chrystusa. Powyższa definicja zawiera $\mathrm{z}$ sobie wszystkie wymienione $\mathrm{w}$ dokumencie założenia aktualizacji. Po takim przedstawieniu aktualizacji od razu widać, czym różni się ona od innych sposobów odnoszenia przesłania Pisma Świętego do życia.

\section{Nowość aktualizacji}

Na wstępie stwierdziliśmy, że aktualizacja, o której mówi dokument Interpretacja Biblii w Kościele, jest nowością. Teraz postaramy się wskazać siedem szczególnych cech, które Papieska Komisja Biblijna nadaje temu procesowi.

1) Szczególne potraktowanie tekstu biblijnego. Dotychczasowe sposoby odniesienia przesłania Pisma Świętego do czasów współczesnych bardzo często akcentują jakąś jedną cechę tekstu biblijnego: interpretacja alegoryczna podkreśla sens zamierzony przez Ducha Świętego, zwany sensem duchowym; lectio divina kładzie nacisk na żywe i aktywne słowo Boże, na usłyszenie Boga; otwieranie Biblii na „chybił trafił” często kończy się instrumentalizowaniem tekstu biblijnego; fundamentalizm do granic możliwości akcentuje bezbłędność Biblii; akomodacja tekstu biblijnego odnosi słowa Biblii do okoliczności niezamierzonych przez autora natchnionego ${ }^{55}$, przekraczając sens Pisma Świętego. Aktualizacja natomiast traktuje tekst jako dzieło powstałe w konkretnym czasie, w konkretnych warunkach, które było przekazywane, interpretowane we wspólnocie

nadal znaczenie dla współczesności. Nic natomiast nie wspomina o chrystologicznym, kanonicznym i eklezjalnym charakterze aktualizacji.

${ }^{55}$ Por. J. Kudasiewicz, Akomodacja tekstu bibl., [w:] Encyklopedia katolicka, red. F. Gryglewicz, R. Łukaszyk, Z. Sułowski, t. 1: A i $\Omega$-Baptyści, Lublin 1973, kol. 244. 
wierzących, a teraz jest czytane przez ludzi też uwarunkowanych przez swoje czasy, i równocześnie jako słowo Boże. Wykorzystując współczesne metody egzegetyczne i zasady katolickiej interpretacji, aktualizacja łączy dwa światy - świat autora tekstu oraz świat czytelnika. Kolejne nowe aspekty aktualizacji wynikają właśnie z tego szczególnego traktowania Biblii.

2) Oparcie aktualizacji na zasadach współczesnej hermeneutyki. Już w pierwszej zasadzie aktualizacji dokument posługuje się wyrażeniem „pełnia sensu biblijnego” lub według tłumaczenia Romaniuka „bogactwo znaczeniowe”. Jak wspomnieliśmy wcześniej, to pojęcie odwołuje się do myśli Ricoeura, a więc podstawowa zasada aktualizacji jest ściśle związana ze współczesną hermeneutyką. Cały proces aktualizacji, opisany w trzech etapach, ma swoje źródło właśnie w filozofiach hermeneutycznych.

3) Oparcie aktualizacji na sensie dosłownym tekstu biblijn ego. Autorzy dokumentu stwierdzają, że aktualizacja musi opierać się na poprawnej egzegezie tekstu. Poprawna egzegeza według komisji to taka, która określa sens dosłowny Pisma Świętego. Dotarcie do sensu dosłownego wymaga natomiast zastosowania metody historyczno-krytycznej $^{56}$. Tak ścisłe powiązanie aktualizacji z poprawną egzegezą jest zasadą wyróżniającą aktualizację od innych sposobów, zwłaszcza tych, które przejaskrawiały bezbłędność Biblii lub skupiały się jedynie na sensie duchowym.

4) Wymiar chrystologiczny, kanoniczny i eklezjalny. Aktualizacja, stawiając w centrum Chrystusa, dokonuje się zgodnie z dynamiczną jednością Biblii i dynamizmem żywej Tradycji. Jak widzimy, aktualizacja, o której mówi dokument, nie pomija żadnego aspektu interpretacji katolickiej.

5) Otwarcie na człowieka i jego mentalność. W dokumencie czytamy, że podczas aktualizacji musimy wziąć pod uwagę ewolucję mentalności ludzi. Jest to kolejna cecha szczególna. Aktualizacja nieustannie musi brać pod uwagę zmiany, jakie następują w myśleniu pojedynczych ludzi lub całych społeczeństw. Aktualizacja rozpoczyna się od

${ }^{56}$ Por. Papieska Komisja Biblijna, Interpretacja..., dz. cyt., s. 32. 
zrozumienia problemów współczesnego świata i człowieka, od antropologicznej i socjologicznej analizy.

6) Otwarcie na nowe metody interpretacji. Według autorów dokumentu aktualizacja nie może ponadto zamykać się w obrębie jakieś jednej metody, lecz ma obowiązek poszukiwać takiej, dzięki której współcześni ludzie mogą lepiej zrozumieć przesłanie Biblii.

7) Wyraźne określenie granic. Szczególne dla aktualizacji jest również to, że komisja wyraźnie wyznacza jej granice. Takie ujęcie ma chronić przed nadużyciami, których bardzo często nie ustrzegły się inne sposoby odnoszenia przesłania Biblii do czasów współczesnych.

Marc Girard ukazuje aktualizację jako jedne z siedmiu otwartych przez dokument drzwi ${ }^{57}$. Niestety, jeśli spojrzymy na bibliografię biblijną, mało kto zechciał przejść przez owe drzwi i zgłębić tak ważny temat. Wiele kwestii, takich jak natura aktualizacji, „bogactwo znaczeniowe" i stosunek do hermeneutyki filozoficznej czy różnorakie metody interpretacji, które można wykorzystać w procesie aktualizacji, należy jeszcze solidnie przestudiować. Mamy nadzieję, że ten artykuł przyczyni się do odkrycia na nowo aktualizacji i zachęci do przechodzenia przez jej drzwi.

\section{Abstrakt}

Aktualizacja Pisma Świętego jest dzisiaj zadaniem koniecznym. Z jednej strony mamy teksty biblijne uwarunkowane przez czasy, w których powstawały, a z drugiej współczesnego czytelnika, również uwarunkowanego swoimi czasami, pragnącego żyć Słowem Bożym. Dokument Papieskiej Komisji Biblijnej Interpretacja Biblii w Kościele z 1993 roku w swej czwartej części podejmuje to zagadnienie. Celem artykułu było przeanalizowanie wypowiedzi dokumentu na temat aktualizacji i przedstawienie jej jako nowego, szczególnego i wciąż nie dość zgłębionego sposobu odniesienia przesłania Biblii do życia współczesnych wierzących.

${ }^{57}$ Por. M. Girard, Dokument Papieskiej Komisji Biblijnej..., dz. cyt., s. 282. 


\section{Słowa kluczowe}

Aktualizacja; interpretacja Biblii w Kościele; Papieska Komisja Biblijna

\section{Abstract}

\section{Actualization of Sacred Scripture According to the Pontifical Biblical Commission's Document “The Interpretation of the Bible in the Church" as a New Way to Refer the Word of God to Life}

The actualization of the Holy Scripture is a necessary task nowadays. On the one hand, we have the Biblical texts conditioned by the times in which they were formed; on the other, we have the the modern reader, also conditioned by his or her times, wanting to live the Word of God. The fourth section of the Pontifical Biblical Commission's 1994 The Interpretation of the Bible in the Church takes up this issue. The aim of this article is to analyze the statements of the document on actualization and to present the process as a new, special and hitherto insufficiently explored way to reference the message of the Bible to the life of believers today.

\section{Keywords}

Actualization; interpretation of the Bible in the Church; Pontifical Biblical Commission

\section{References}

Papieska Komisja Biblijna Interpretacja Biblii w Kościele, [w:] Interpretacja Biblii w Kościele. Dokument Papieskiej Komisji Biblijnej z komentarzem biblistów polskich, przekł. i red. R. Rubinkiewicz, Warszawa 1999, s. 24-101.

Papieska Komisja Biblijna, Interpretacja Pisma Świętego w Kościele. Przemówienie Ojca świętego Jana Pawła II oraz Dokument Papieskiej Komisji Biblijnej, tłum. K. Romaniuk, Poznań 1994.

Burkhard J. J., The use of Scripture in theology and preaching: experience, interpretation and ecclesial identity, „New Theology Review” 8 (1995) nr 1, s. 30-44. 
Fitzmyer J. A., The Biblical Commission's document „The interpretation of the Bible in the Church", Roma 1995.

Fitzmyer J. A., Concerning the Interpretation the Bible in the Church, [w:] The interpretation of Scripture. In defense of the historical-critical method, New YorkMahwah 2008, s. 74-85.

Girard M., Dokument Papieskiej Komisji Biblijnej „Interpretacja Biblii w Kościele” bilans i perspektywy, „Verbum Vitae” 2003 nr 4, s. 269-283.

Haręzga S., Droga Słowa Bożego od zrozumienia do inkulturacji, [w:] Interpretacja Biblii w Kościele. Dokument Papieskiej Komisji Biblijnej z komentarzem biblistów polskich, przekł. i red. R. Rubinkiewicz, Warszawa 1999, s. 196-217.

Kudasiewicz J., Akomodacja tekstu bibl., [w:] Encyklopedia katolicka, red. F. Gryglewicz, R. Łukaszyk, Z. Sułowski, t. 1: A i $\Omega$-Baptyści, Lublin 1973, kol. 244-245.

Laconi M., Nella vita della Chiesa, [w:] Pontificia Commissione Biblica, L'interpretazione della Bibbia nella Chiesa. Commento, a cura di G. Ghiberti, F. Mosetto, Torino 1998.

Murphy R. E., Reflections on „actualization” of the Bible, „Biblical Theology Bulletin” 26 (1996) nr 2, s. 79-81.

Pindel R., Aktualizacja wedtug Dokumentu Papieskiej Komisji Biblijnej „Interpretacja Biblii w Kościele”, [w: Z Z badań nad Biblią, red. T. Jelonek, t. 5, Kraków 2002, s. 9-26. Ricoeur P., Interpretation Theory: Discourse and the Surplus of Meaning, Fort Worth 1976. Sobór Watykański II, Konstytucja dogmatyczna o Objawieniu Bożym „Dei Verbum”, Wrocław 2003.

Uliasz J., L'attualizzazione del messaggio biblico, „Studia Sandomierskie. Filozofia Teologia - Historia” 14 (2007) z. 2-4, s. 321-347.

Williamson P. S., Actualization: a new emphasis in catholic Scripture study, „America” $1995 \mathrm{nr} 172$, s. $17-19$.

Williamson P. S., Catholic principles for interpreting Scripture, „Catholic Biblical Quarterly" 65 (2003) nr 3, s. 327-347.

Williamson P. S., Catholic principles for interpreting Scripture: a study of the Pontifical Biblical Commission's "The interpretation of the Bible in the Church”, Roma 2001. 
